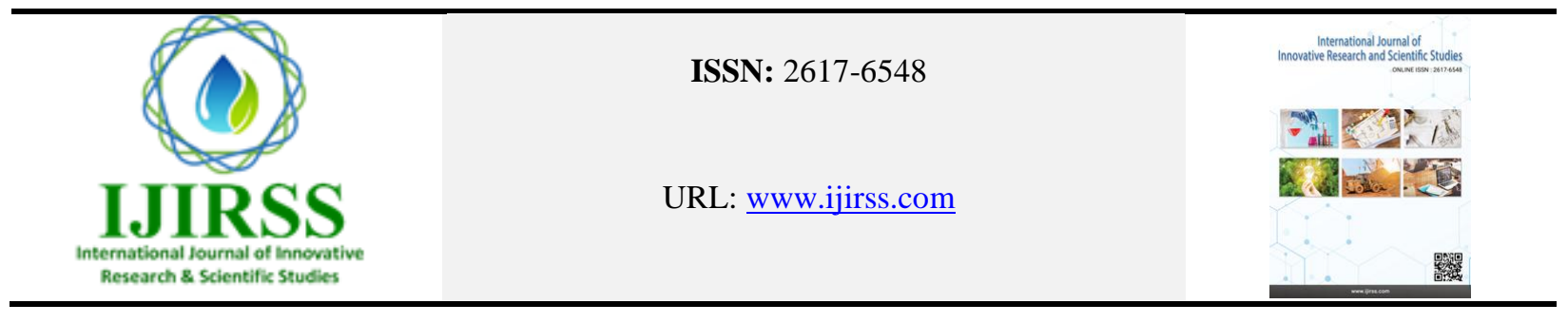

\title{
Impact of Solar Heating Technology Installation on Reduction of Greenhouse Gas Emissions in Kabul City
}

\author{
Nisar Ahmad Rahmany ${ }^{1 *}$, Mohammad Hamed Patmal ${ }^{2}$ \\ ${ }^{1}$ Department of Energy Engineering, Kabul University, Jamal Mina 1006, Afghanistan \\ ${ }^{2}$ Department of Electrical and Electronics Engineering, Kabul University, Jamal Mina 1006, Afghanistan \\ *Corresponding author: Nisar Ahmad Rahmany (nisar.rahmany@gmail.com)
}

\begin{abstract}
The increasing trend of air pollution in Kabul listed this city, one of the most polluted in the world. The air pollution in Kabul contrasting to other polluted cities in the world is seasonal pollution. According to some reports during the winter season as the demand for heating increases, the majority part of the households and industries in cities use biomass and low-quality fossil fuels to meet their energy demand. The increase of greenhouse gases (GHG) emissions due to the use of conventional energy resources, especially raw coal considered a serious threat to people's lives in Kabul. Due to the abundance of solar energy radiation and the simplicity of technologies, Solar Heating (SH) installation on the rooftop of houses is one of the most prominent solutions to minimize environmental impacts and air pollution related diseases in Kabul. The primary objective of this paper is to assess the potential of GHG reduction with the use of $\mathrm{SH}$ technologies in houses. Additionally, the impact of SH installation on non-renewable energy consumption and electricity bill reduction is deliberated in this paper as well. This study is supported by a public web-based survey, which is designed for municipal planned and non-planned areas in Kabul city. The results of the study indicate, due to poor reliability of electric energy supply, most of the population in Kabul city rely on polluted energy sources to meet their primary demand. The study also points; housing sector in Kabul has the biggest portion of energy consumption, which is mainly used for heating purposes. Employing solar thermal technologies in households can significantly decline the utilization of coal and firewood, which in turn leads to a substantial reduction in GHG emissions. This study could be a good reference for the policymakers and investors in the field of green energy in Afghanistan.
\end{abstract}

Keywords: Greenhouse Gas Emission, Solar Heating, Energy Consumption, Renewable Energy. 
DOI: $10.53894 /$ ijirss.v4i2.56

Funding: This study received no specific financial support.

History: Received: 11 January 2021/Revised: 16 February 2021/Accepted: 12 March 2021/Published: 30 March 2021

Licensed: This work is licensed under a Creative Commons Attribution 4.0 License (cc) EY

Acknowledgement: This study was conducted in September and November 2020 through a web-based survey to determine the potential of solar thermal technologies application in GHG reduction in Kabul city households. Here, I would like to take the opportunity to thank the colleagues, friends, students, and other participants who have dedicated their time to participate in the research survey and assisted me to enrich this research.

Competing Interests: The authors declare that they have no conflict of interests.

Transparency: The authors confirm that the manuscript is an honest, accurate, and transparent account of the study was reported; that no vital features of the study have been omitted; and that any discrepancies from the study as planned have been explained. Ethical: This study follows all ethical practices during writing.

\section{Introduction}

Kabul city is one of the fast-developing and densely populated cities in the world. Most of the people in Kabul city experiencing regular power outages throughout the year. During the winter as the power demand rise the load, shedding expands which mainly due to an increase in heating load. In this case, most people are compelled to consume alternative sources of energy including gas, coal, and biomass to meet their primary demand [1].

The growing trend of Kabul city augmented the primary energy supply for alternative energy sources. Coal is the most prominent fuel among the others, which comprises the biggest share in greenhouse gas emissions. Households are the biggest coal and biomass consumer during winter in Kabul city and Over 70\% of the household's energy is used to heat space and water [1]. Covering a large portion with a solar system leads to energy as well as financial savings, which also have an essential impact on environmental pollution [2].

\section{Solar Heating Systems Technologies}

Solar thermal energy is a suitable option for both heating and cooling applications. Solar thermal technologies are an environmentally friendly solution for applications such as domestic water heating, space heating, and pool heating, drying process, and certain industrial processes and applied in numerous projects worldwide. Solar heating systems can be broadly classified in two categories: (1) active solar systems and (2) passive solar systems. Active solar systems require electrically powered pumps or blowers to circulate the thermal transport fluids utilized by the system. Passive solar systems collect and utilize solar energy by natural means and do not involve the use of mechanical power to circulate the heat transport fluid [3].

The Figure 1 represent a typical solar thermal system with its main componets and the solar collectors types are described in the preceeding sections.

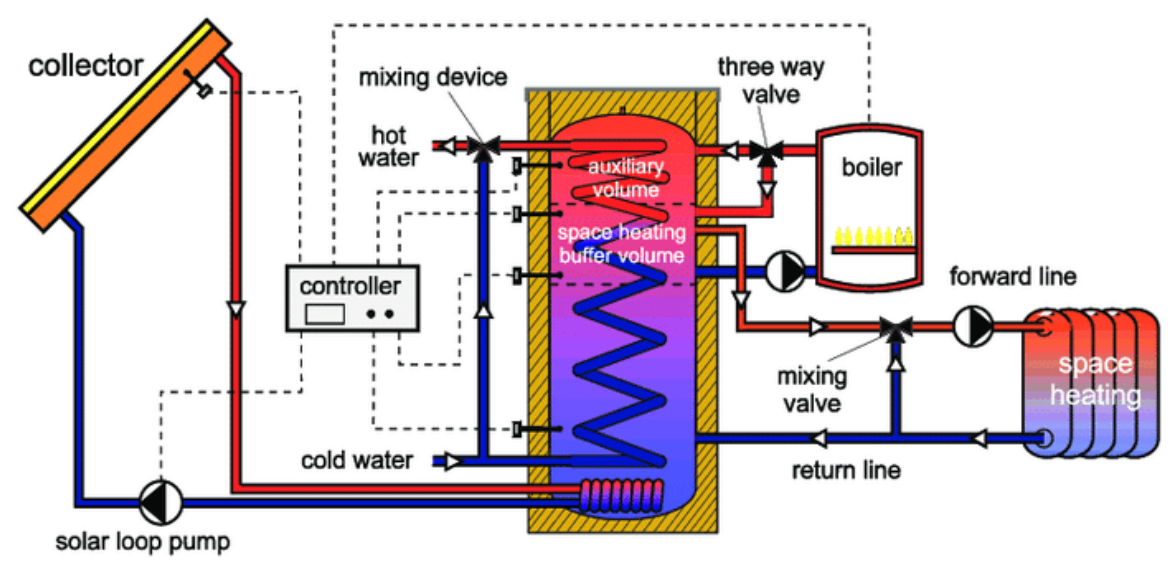

Figure-1.

A typical solar thermal system [4]. 
Flat-plate-collectors: These solar collectors have the biggest usage on the market and are a popular option for the application of domestic hot water production. Tube connection (coupling of the tubes with the absorber) issue is the most serious issue that affects the performance of the flat-plate collectors. This solar heating technology is mostly installed on a simple supporting structure and for the pitched roof; it is usually integrated with the sloped surface of the roof [2].

Evacuated tube collectors: Evacuated Tube Collectors (ETCs) can achieve temperatures above $200^{\circ} \mathrm{C}$. There are various types of ETCs, and a typical collector is shown on Figure 2. ETCs are typically designed with parallel rows of twin glass tubes, with each inner glass tube containing a metal heat pipe attached to an absorber fin. The air between the two glass tubes is removed (or evacuated) to form a vacuum, which reduces conductive and convective heat loss [5].

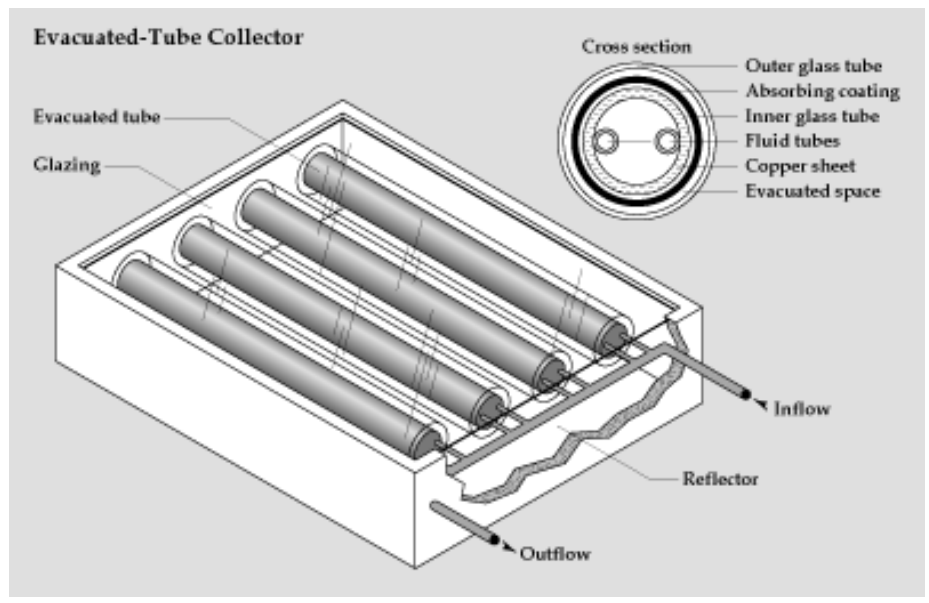

Figure-2.

A typical solar thermal system [5].

Solar air collectors: Solar air collectors (SACs) are a type of solar thermal collectors that use solar radiation to actively deliver warm air into buildings. Typically deployed onto surfaces of a building with a southerly aspect, the technology has a proven record and great potential as an available and cost-effective means of space heating [6].

\section{Afghanistan solar resource}

Afghanistan on average has 300 sunny days can take benefit from this bulk amount of solar energy by employing different technologies. Solar energy has the most potential among all renewable energy sources in Afghanistan, which is abundant and environmentally friendly. Afghanistan can potentially produce 220,000 MW of solar power with 300 sunny days each year and can generate $6.5 \mathrm{kWh} / \mathrm{m} 2$. The southern and western parts of Afghanistan receive even more direct sunlight and can potentially generate $1022 \mathrm{KW} / \mathrm{m}^{2} /$ year or more with the installation of concentrating solar power (CSP) which is indicated in Figure 3 [7].

As the population is increasing the demand for water heaters and space heating technologies following the same trend. People are mostly using coal and wood for heating during the cold season. However, we cannot find any report to show that renewable energy consumption causes $\mathrm{CO}_{2}$ emissions [8]. From 2000 to the present people are tending to extend the use of renewable energy technologies, such as solar heating technology for buildings in Europe that people are developing building-integrated photovoltaic BIPV modules [9-11]. Solar 
heating technologies are mainly used for hot water and space heating purposes that are installed on the rooftop of buildings [12-14].

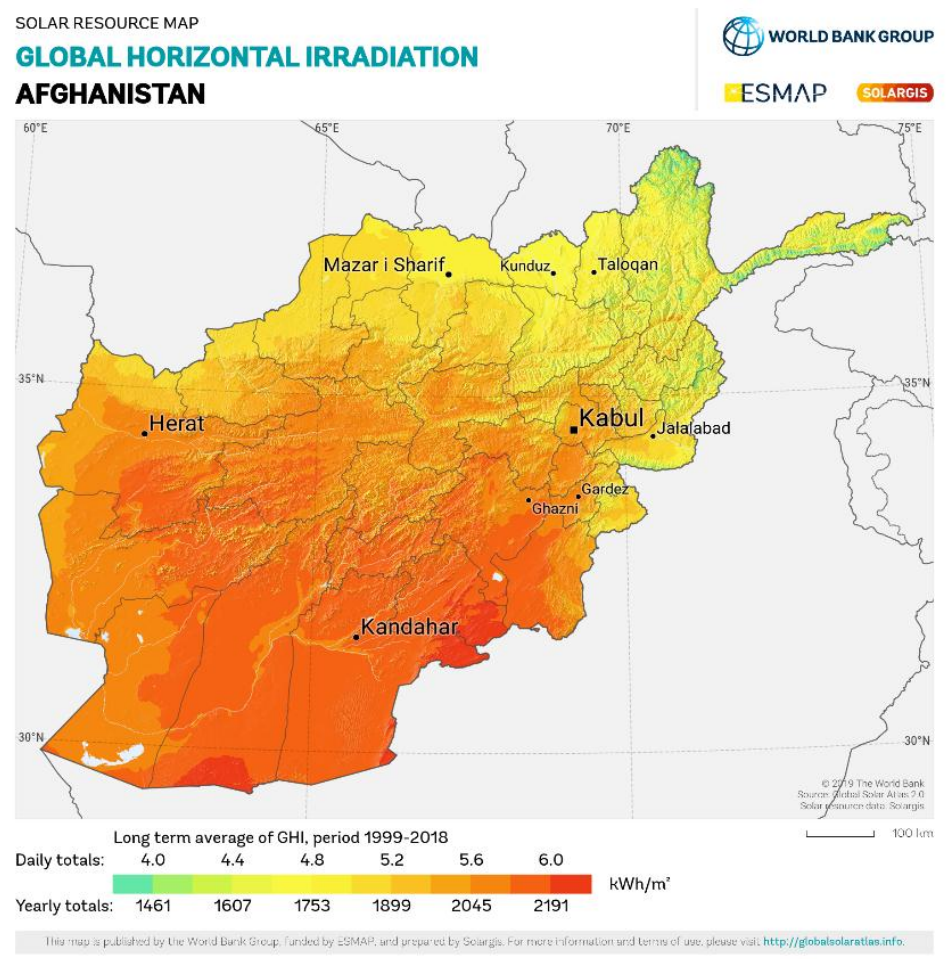

Figure-3.

Solar radiation map of Afghanistan [7].

There are several papers to show that RET use will directly affect to reduce the greenhouse gas emissions as reported in [15]. The current conventional use of global energy use of fossils and other GHG-rich sources such as coal negatively affects people's lives, land, and culture; it is recommended to consider the people's concerns in highest priority [16]. There is a direct relation between $\mathrm{CO}_{2}$ emissions and the financial resources of people [17].

[18] Reports that people in Pakistan are using natural gas as an energy source for cooking and water heating purposes. The use of solar water heaters instead that of domestic water heaters can reduce the demand for natural gas and can help the green environment and reduce the GHG emissions of the environment. Since the conventional energy, sources are causing damages to human lives. Lawyers for the related public-private organizations are responsible for continuously warn customers about the damages due to the emissions of GHGs and climate change, and therefore, they need to be well aware of these risks [19].

The solar heating technologies are not effective for long distances; however, it is very effective if used close to the buildings [20].

\section{Research Questions}

To achieve the objectives of this research, we have to meet the following research questions.

Research question 1: How much is the potential GHG reduction if solar heating technologies are used in residential housings?

This research will assess the potential of GHG Reduction with the use of Solar Heating (SH) Technologies in residential houses to provide water and space heating demand. 
Research question 2: How much would the demand for non-renewable energy sources will decrease with the installation of solar heating technologies?

The impact of the installation of solar heating technologies on the public use of non-renewable energy resources in residential houses will be evaluated in the research.

Research question 3: How much would be the savings of electricity consumption, when the solar heating technologies are used in residential houses.

\section{Methodology}

The primary research method for this study is a literature review and web-based survey. The web-based questionnaire was modeled based on the objective of the research, which targeted the population in Kabul city. The survey was conducted between September and November 2020 and the data for the results were selected through a random sampling process. The questionnaire with an option to prevent participant's duplication reply was developed in Google Docs platform and was disseminated using various communication networks including email, social media, and messaging apps.

The questionnaire was designed to collect data with 13 questions. Questions 1 to 5 have asked demographic data to declare the number of people per family, the number of rooms for space heating, rooftop areas, urban/rural areas, and the districts they live. Questions 6 to 8 collected data for main energy sources for hot water demand, family average hot water demand, and main energy resources for space heating. Questions 9, 10, and 11 asked about family average monthly electricity, coal, and wood consumption respectively. The last two questions 12 and 13 asked about the number of coal-fired stoves and electric boilers the family use during the winter season. We used simple percentage calculations for the analysis of collected data.

\section{Results}

\subsection{Demographic Characteristics}

The number of participants in the survey was overall 128 individuals where each of them representing one family. The survey contains a question to distinguish participants living location in Kabul city. The Kabul city was considered in six geographical zones where each zone comprising multiple municipal districts. Table 1 summarize the characteristic of the participants based on their location.

Table-1.

Location versus the number of participants

\begin{tabular}{l|c|c}
\hline Location Characteristic & Frequency & Percentage (\%) \\
\hline Western Parts of Kabul City & 38 & 29.69 \\
\hline Eastern Parts of Kabul City & 12 & 9.38 \\
\hline Southern Parts of Kabul City & 16 & 12.50 \\
\hline Northern Parts of Kabul City & 21 & 16.41 \\
\hline Central Parts of Kabul City & 19 & 14.84 \\
\hline Neighboring districts of Kabul City & 22 & 17.19 \\
\hline Total & 128 & 100 \\
\hline
\end{tabular}

Although the survey was designed for those who live in Kabul city, however, according to the results $17.2 \%$ of the respondents were living in neighboring districts of Kabul city. The questionnaire comprises demographic- 
related questions to find out the number of persons per family in Kabul city. Table 2 shows the respondent's family size and their frequency in Kabul city from different geographical zones.

Table-2.

Frequencies of participants according to number of individuals per family.

\begin{tabular}{l|c|c}
\hline Number of Individuals Per Family & Frequency & Percentage (\%) \\
\hline Twelve Persons & 28 & 21.88 \\
\hline Ten Persons & 2 & 1.56 \\
\hline Six Persons & 2 & 1.56 \\
\hline Nine Persons & 30 & 23.44 \\
\hline Three Persons & 10 & 7.81 \\
\hline Five Persons & 34 & 26.56 \\
\hline Seven Persons & 22 & 17.19 \\
\hline Total & 128 & 100 \\
\hline
\end{tabular}

According to the above results, the average number of individuals per family is 7.75 , which can be as round as eight and taken as a reference number to estimate the total number of families in Kabul city.

\subsection{Characteristics of Kabul city households}

The survey includes queries pertinent to the physical characteristics of the participant's house to determine the number of rooms to be heated during cold seasons. Table 3 summarizes the participant's number of rooms that are heated throughout winter.

Table-3.

Number of rooms for heating in households and its frequencies

\begin{tabular}{l|c|c}
\hline Number of rooms to be heated & Frequency & Percentage (\%) \\
\hline 1 Room & 44 & 34.38 \\
\hline 2 Room & 30 & 23.44 \\
\hline 3 Room & 16 & 12.50 \\
\hline 4 Room & 28 & 21.88 \\
\hline 5 Room & 10 & 7.81 \\
\hline Total & 128 & 100 \\
\hline
\end{tabular}

Table-4.

Participants households' rooftop area and its frequencies

\begin{tabular}{l|c|c}
\hline Estimated rooftop area & Frequency & Percentage (\%) \\
\hline $100 \mathrm{~m}^{2}$ & 42 & 32.81 \\
\hline $150 \mathrm{~m}^{2}$ & 32 & 25.00 \\
\hline $200 \mathrm{~m}^{2}$ & 42 & 32.81 \\
\hline$>=300 \mathrm{~m}^{2}$ & 8 & 6.25 \\
\hline Apartment no rooftop & 4 & 3.13 \\
\hline Total & 128 & 100 \\
\hline
\end{tabular}


As the results show, the majority of the population in Kabul city not heating more than two rooms in their houses which may be due to the economic affordability of the people to purchase heating fuels. Table 4 shows the estimated rooftop area of the houses in Kabul, which is imported to know for SH technology installation.

The above results provide information for the technical feasibility of SH systems installation at residential houses in Kabul city. According to the above findings, only a small percentage of the Kabul population resides in apartments and most of the family living in flat houses which have sufficient free space on their rooftop for SH installation.

\subsection{Main Fuels for Heating in Kabul City}

Due to the shortage of electric energy in Kabul city during the cold season, the majority of their population utilize other sources specifically raw coal and woodfire to satisfy their energy demand for heating purposes. The following illustrates the monthly usage of each of these fuels and its frequency among the participants during the cold period.

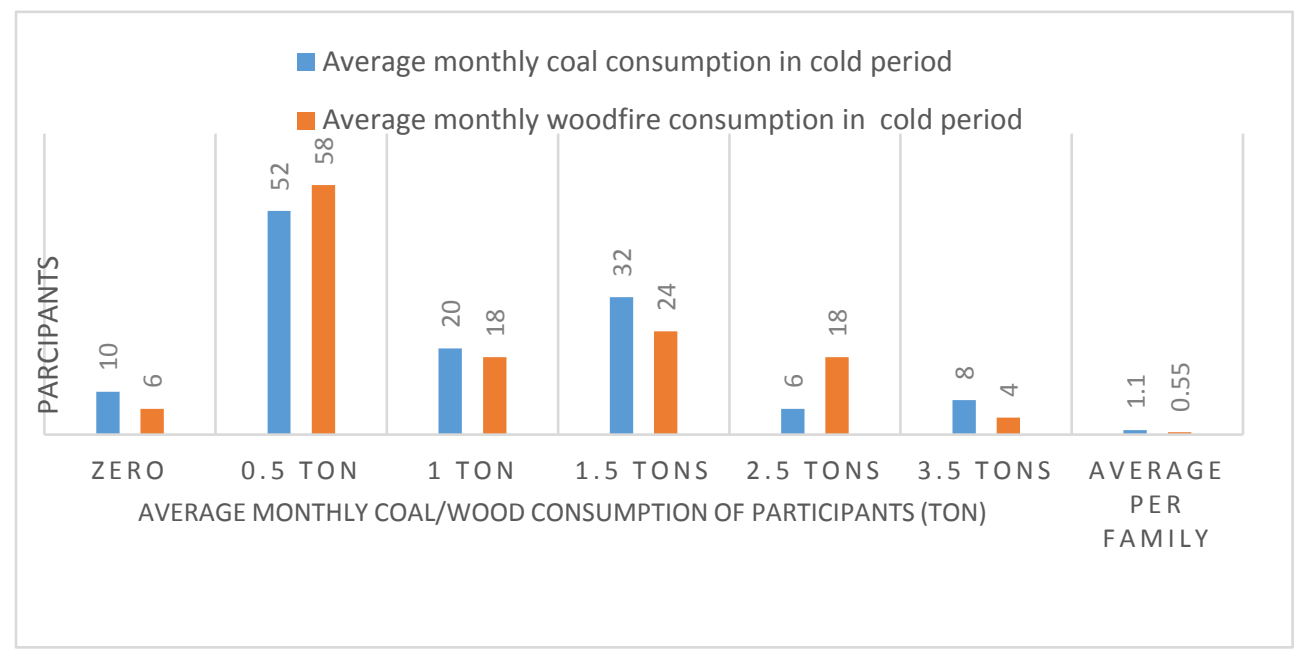

Figure-4.

Average Monthly Coal \& woodfire Consumption per Family

From the findings in Figure 4, the average coal and woodfire monthly consumption per family in Kabul city estimated is 1.1 and 0.55 ton respectively. This value has been used as a reference to estimate the total monthly GHG emissions caused by mentioned fuels during the cold season in Kabul city.

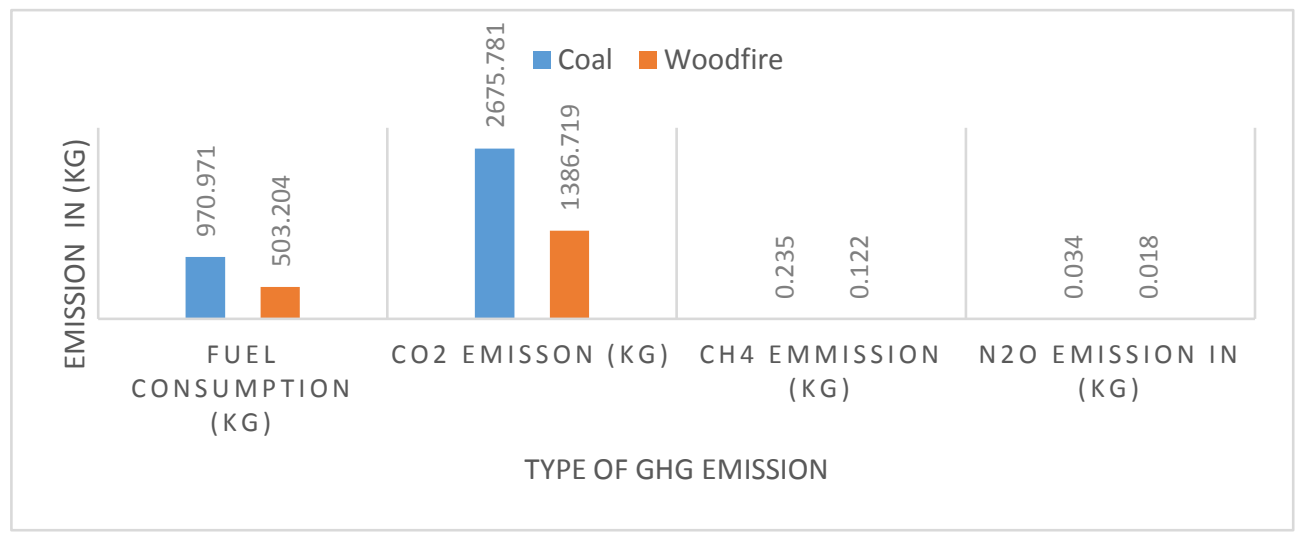

\section{Figure-5.}

Average Monthly GHG Emission per Family due to in Kabul City 
As the results in Fig.5 indicates, carbon dioxide has the highest potion in GHG emissions among all heating fuels in Kabul city during winter. The average number of individuals per family was estimated from the survey findings and the total family number in Kabul city was then calculated by dividing the Kabul population by the calculated individual per family. As per the questionnaire results, the monthly average fuel consumption for coal and wood consumption was determined. Based on the calculated monthly fuel consumption, the total number of families, and the emission factor for both coal and wood, the greenhouse gas emission was calculated which is summarized in Table 5 .

Table-5.

GHG Emission Reduction by Employing SH in Residential Housing in Kabul City

\begin{tabular}{l|l}
\hline Estimated Kabul Population (2020) & $4,273,000.00$ \\
\hline Average Persons in Each Family as per finding (Person) & 8.00 \\
\hline Total Average Estimated Number of Families in Kabul city & $534,125.00$ \\
\hline Average Monthly Wood Consumption per family in the cold season (Kg) & 503.20 \\
\hline Average Monthly Coal Consumption per family in the cold season (Kg) & 970.97 \\
\hline Total estimated monthly wood consumption in Kabul city during the cold season (ton) & $268,773.86$ \\
\hline Total estimated coal consumption in Kabul city during the cold season (ton) & $518,619.97$ \\
\hline Total Estimated Monthly $\mathrm{CO}_{2}$ Emission due to wood consumption (ton) & $816,461.21$ \\
\hline Total Estimated Monthly $\mathrm{CO}_{2}$ Emission due to coal consumption (ton) & $1,575,425.16$ \\
\hline Total Estimated Monthly $\mathrm{CH}_{4}$ Emission due to wood consumption (ton) & 71.85 \\
\hline Total Estimated Monthly $\mathrm{CH}_{4}$ Emission due to coal consumption (ton) & 138.64 \\
\hline Total Estimated Monthly $\mathrm{N}_{2} \mathrm{O}$ Emission due to wood consumption (ton) & 10.45 \\
\hline Total Estimated Monthly $\mathrm{N}_{2} \mathrm{O}$ Emission due to coal consumption (ton) & 20.17 \\
\hline Total Estimated Monthly $\mathrm{GHG}$ Emission due to coal \& woodfire (mton) & 2.39 \\
\hline
\end{tabular}

\subsection{Electricity Saving Potential}

Per capita, electricity consumption in Afghanistan averages 186 kilowatt-hours (kWh) per year, which is far below the global average of 3,126 kWh. We assume this amount is the same for Kabul city during the winter, during one month approximately 46362 Mwh of electrical energy can be saved as shown in Table 6.

Table-6.

Electricity Saving Potential by employing SH technologies in Kabul city households.

\begin{tabular}{l|l}
\hline Annual per capita average electrical energy consumption (kwh) & 186 \\
\hline Monthly per capita average electrical energy consumption (kwh) & 15.5 \\
\hline Monthly per capita electricity consumption for heating (taken 70\%) (kwh) & 10.85 \\
\hline Number of persons per family (from results) (number) & 8 \\
\hline Average monthly electricity consumption per household (kwh) & 86.8 \\
\hline Total Average Estimated Number of households in Kabul city & 534125 \\
\hline Approximate monthly electricity saving for whole Kabul city (Mwh) & 46362.05 \\
\hline
\end{tabular}




\section{Conclusion and Recommendation}

The purpose of this study was to evaluate the impact of the installation of solar heating technologies on the public use of non-renewable energy resources in residential houses. A web-based survey was conducted to examine the usage of $\mathrm{CO}_{2}$ rich energy resources for heating purposes in residentials.

Despite the results of the study designates on average there is eight individual per family at Kabul city however, our results show that, most of the families heating two rooms in their dwellings. Moreover, the study shows due to the unreliable supply of electricity by the utility company in Kabul city, the people are obliged to use other polluted sources for heating during the cold seasons. The results demonstrate during the cold seasons, on average each family monthly produces 4062 kilograms of greenhouse gases $\left(\mathrm{CO}_{2}, \mathrm{~N}_{2} \mathrm{O} \& \mathrm{CH}_{4}\right)$ and concerning this value, approximately $2.39 \mathrm{mton}$ of $\mathrm{GHG}$ emits in one month during winter.

As per the energy consumption behavior and solar resource availability, the application of solar heating technology in residential housing is technically feasible in most households in Kabul city. However, this requires more detailed technical investigation including sustainability of SH systems specifically during the harsh cold weather and cloudy periods in winter. Additionally, the economical viability of this technology for Kabul city families needs to be calculated.

\section{References}

[1] M. S. S. Danish, N. R. Sabory, S. M. S. Danish, T. Senjyu, G. A. Ludin, A. S. Noorzad, and A. Yona, "Electricity sector transitions in an after war country: A review of Afghanistan's electricity," International Journal of Energy and Power Engineering, vol. 11, pp. 491-496, 2017

[2] M. Treberspurg and H. Djalili, "BOKU, New technical solutions for energy-efficient buildings: State of the Art Report Solar heating \& cooling," 2011.

[3] J. R. Williams, "12 - solar energy for heating and cooling, Editor(s): A.E. DIXON, J.D. LESLIE," Solar Energy Conversion, Pergamon, pp. 377-391, 1979.

[4] J. Vourdoubas, "Description and assessment of a small renewable energy community in the Island of Crete, Greece," Open Journal of Energy Efficiency, vol. 06, pp. 97-111, 2017. Available at: 10.4236/ojee.2017.63008.

[5] K. Hudon, Chapter 20 - solar energy - water heating, Editor(s): Trevor M. Letcher, Future Energy, 2 nd ed.: Elsevier, 2014.

[6] M. A. Paya-Marin, Chapter 5 - solar air collectors for cost-effective energy-efficient retrofitting: Woodhead Publishing, 2017.

[7] A. K. Slimankhil, M. A. Anwarzai, N. R. Sabory, M. S. S. Danish, M. Ahmadi, and M. H. Ahadi, "Renewable energy potential for sustainable development in Afghanistan," Journal of Sustainable Energy Revolution, vol. 1, p. 1068, 2020.

[8] Q. Wang and R. Li, "Research status of shale gas: A review," Renewable and Sustainable Energy Reviews, vol. 74, pp. 715720, 2017. Available at: 10.1016/j.rser.2017.03.007.

[9] A. G. Hestnes, "Building Integration of energy systems," Solar Energy, vol. 67, pp. 181-187, 1999. Available at: 10.1016/S0038-092X (00)00065-7.

[10] T. Yang and A. K. Athienitis, "Experimental investigation of a two-inlet air-based building integrated photovoltaic/thermal (BIPV/T) system," Applied Energy, vol. 159, pp. 70-79, 2015. Available at: 10.1016/j.apenergy.2015.08.048.

[11] F. Motte, G. Notton, C. Cristofari, and J. L. Canaletti, "Design and modelling of a new patented thermal solar collector with high building integration," Applied Energy, vol. 102, pp. 631-639, 2012. Available at: 10.1016/j.apenergy.2012.08.012.

[12] J. H. Yoon, S. R. Sim, U. Shin, N. C. Baek, and H. Y. Kwak, "A study on the optimum application method of solar thermal system to reduce thermal load and carbon emission in apartment building," Journal of the Korean Solar Energy Society, p. 31, 2011.

[13] R. L. Shrivastava, V. Kumar, and S. P. Untawale, "Modeling and simulation of solar water heater: A TRNSYS perspective," Renewable and Sustainable Energy Reviews, vol. 67, pp. 126-143, 2017. Available at: 10.1016/j.rser.2016.09.005.

[14] P. Valdiserri, "Evaluation and control of thermal losses and solar fraction in a hot water solar system," International Journal of Low-Carbon Technologies, vol. 13, pp. 260-265, 2018. Available at: 10.1093/ijlct/cty02.

[15] Z. Zoundi, "CO2 emissions, renewable energy and the Environmental Kuznets Curve, a panel cointegration approach," Renewable and Sustainable Energy Reviews, vol. 72, pp. 1067-1075, 2017. Available at: https://doi.org/10.1016/j.rser.2016.10.018.

[16] N. Heidari and J. M. Pearce, "A review of greenhouse gas emission liabilities as the value of renewable energy for mitigating lawsuits for climate change related damages," Renewable and Sustainable Energy Reviews, vol. 55, pp. 899-908, 2016. Available at: doi.org/10.1016/j.rser.2015.11.025.

[17] K. Saidi and M. B. Mbarek, "Nuclear energy, renewable energy, CO2 emissions, and economic growth for nine developed countries: Evidence from panel Granger causality tests," Progress in Nuclear Energy, vol. 88, pp. 364-374, 2016. Available at: 10.1016/j.pnucene.2016.01.018.

[18] K. Harijan and M. A. Uqaili, "Potential of solar energy for cooking in rural areas of Pakistan," in Proceedings, World Renewable Energy Congress-IX, Florence, Italy, August 19-25, Elsevier Science Ltd., U.K, 2013.

[19] K. Healy and J. Tapick, "Climate change: It is not just a policy issue for corporate counsel - it is a legal problem," Columbia Journal of Environmental Law, Entvl. L, vol. 89, pp. 1-23, 2004.

[20] Korea Energy Agency, New \& renewable energy supply statistics 2014. Yongin, Korea: Korea Energy Agency, 2015. 